\title{
The Importance of Entrepreneurship Learning in University: An Empirical Research
}

\author{
Dhurata Turku \\ "Aleksanër Xhuvani” University, Elbasan \\ Dhurata. turku@yahoo.com
}

\begin{abstract}
After finishing the university, students usually do not know what to do. Most of them cannot find a job. Based on our mentality, working is considered by the student an employment with a salary, mainly in public sector or in private sector based on the diploma university. If this does not function, the graduated student calls him/herself unemployed and does not hope for his future. Salary employment is not and cannot be the only solution in everyone's life. If a student is graduated and cannot find a job based on a salary, he/she may use his/her abilities about entrepreneurship that he/she has learnt at university. To be self-employed does not need the condition o having a diploma in economic studies. Everyone that has a diploma and who does not have a job based on a salary, may be a successful selfemployed. A very important role is the entrepreneurship learning during studies. Such an education would be necessary for all the students in all university branches. To know how much our students know about entrepreneurship and which are their needs in relation to the entrepreneurship, there are analyzed and concluded questionnaires and interviews with 283 students of Education Sciences in "Aleksandër Xhuvani" University, Elbasan.
\end{abstract}

Keywords: Education, entrepreneurship student, competence, university.

\section{Purpose}

The purpose of this research is analyzing gathered information from questionnaires done by students of Education Sciences in "Aleksandër Xhuvani" University, Elbasan in elementary and kinder garden teachers to be, in order to identify and categorize their needs in relation to entrepreneurship learning.

\section{Methodology}

This research is based on the questionnaires done by students of teaching branches, mostly elementary and kinder garden teachers in order to draw conclusions. The research is based on this group/sample because it is thought that entrepreneurship learning should start since in elementary education and kinder gardens; moreover, only the future teachers of elementary can do that.

\section{Introduction}

After finishing studies, students do not know what to do. Most of them cannot find a job. Based on our mentality, working is considered by the student an employment with a salary mainly in public sector or in private sector based on the diploma university. If this does not function, the graduated student calls him/herself unemployed and does not hope for his future. What student should know is the fact that during their studies they should understand that their career can be divided in two categories:

Salary employment 
Self-employer (entrepreneurship) ${ }^{1}$

The term career means a continuous opportunity that is always developing. This development implies personal and business progress. Salary employment is not and cannot be the only solution for a living and its quality. Entrepreneurship can be another better option for everyone's career instead of salary employment. Salary employment means working for others and being paid by a salary, whereas entrepreneurship means entrepreneurship.

In the following chart, there are given the main differences of two manners to be successful in the career.

\begin{tabular}{|l|l|}
\hline Salary employment & Entrepreneurship \\
\hline Works for others & - The boss of yourself \\
Follows orders & - Makes your own plans \\
Routine job & $-\quad$ Creative activities \\
Fixed earnings & - Sometimes it can be negative, in general; the balance \\
Does not set money aside & is positive \\
Has possibilities to choose among: & - Sets money aside \\
Governmental services & $-\quad$ Can choose from fields: \\
Public sector & $-\quad$ Industry \\
Private sector & - Trading \\
& - services \\
\hline
\end{tabular}

A self employer creates his/her own business. He/she looks for the difference and responds to it. There are some definitions about entrepreneurship, the simplest is: a self employer is someone who has possibilities, organizes the necessary resources to use the possibilities and in the end uses them. Entrepreneurship includes creativity, innovation, taking risks and the ability to plan and manage projects in order to reach the objectives. Entrepreneurship is applicable for big businesses and small ones as well; for economic activities and non-economic ones.

There are two concepts about entrepreneurship: ${ }^{2}$

The narrow concept of entrepreneurship, as an ability to start and develop a business;

The wider concept of entrepreneurship as a "complex ability" to take initiatives, to face up risks and to be successful in life.

It is important to understand that entrepreneurship is not only an economic category. Entrepreneurship thinking and acting is noticed in all functional system of society such as economy, religion, science, politics, education and even sport. Every individual can be a self-employer in a specific field. To start an entrepreneurship does not need the condition of having a diploma in economic field. Everyone who does not have this diploma, but has another diploma and does not have the possibility to be salary employed or is looking for another option, can be a successful self-employer. A very important role in this field has the entrepreneurship learning since at school. Such education would be necessary for all the students in different faculty branches that they study.

\section{What is entrepreneurship learning?}

If entrepreneurship is named as "entrepreneurial spirit" (with entrepreneurial spirit it is understood the knowledge and chances organization), entrepreneurial learning stresses out the learning component; which means learning for entrepreneurship. The concept of entrepreneurship learning comes from USA where it is also developed as a term. Entrepreneurship cannot be confused with business studies and economy, its purpose is to offer the individual some

\footnotetext{
${ }^{1}$ Robo, M., Xhavara, A., Bazat e Sipërmarrjes, Tiranë 2012, p 8.

2 Robo, M., Xhavara, A., Bazat e Sipërmarrjes, Tiranë 2012, p 14-15.
} 
characteristics that can make individuals be successful self employers. If a student is graduated and cannot find a salary job, he/she can use his/her abilities learnt at school in order to be self-employed. This is an option that should be taken into consideration. However, not everything can be absolute. Entrepreneurial learning is a necessity nowadays and school should fulfill this important mission, bur not everything can be learnt at school. American professor of self - employing Brukhauz ${ }^{1}$ explains the possibility of entrepreneurial learning by comparing: he asks a question: Can anyone be learnt to be an artist? Then, he answers:

-Yes, it is possible to teacher people the theory of colors, composition, art and other artistic abilities, but it cannot be taught to be the second Picasso or Van Gogh. The same thing happens in entrepreneurial learning. It can be taught the basic skills of entrepreneurship but abilities that are difficult to be taught and transmitted for example resistance, devotion, loyalty abilities etc are born and gifted and are difficult to be taught. In relation to our country, recently it is often mentioned the topic about entrepreneurial learning in university. Education Council has approved a concrete report since $2001^{2}$ in order to indentify the main abilities that an individual should have where there are composed eight basic competences in eight fields:

\section{Communication in native language}

Communication in foreign languages

Mathematics knowledge and science \& technology competence

Digital competence

Learning competence

Sense of initiative and entrepreneurship

Civic competence

Cultural informing

Entrepreneurship is considered as one of eight key competences of individual abilities and is determined as an ability to put ideas in action. It involves creativity, innovation taking risks and the ability to plan and manage projects in order to reach objectives $^{3}$. Based on the European Union, entrepreneurial learning includes three components ${ }^{4}$ :

Personal development (motivating progress, the power of thought and entrepreneurship, the desire to be inspired and to be successful)

Business development (knowledge and technical, financial abilities to be self-employed or entrepreneurship that can lead to self-employment)

Developing entrepreneurial abilities (training for social abilities, networking, creative solutions to problems, opportunities research, sales, interviews, presentations etc.)

Entrepreneurship learning is important in all levels of education. We are going to focus o university entrepreneurship, in universities that prepare future teachers in elementary education (in "Aleksandër Xhuvani" University, Elbasan in our case), who should aim to transmit entrepreneurship learning in their pupils since in elementary level.

\footnotetext{
${ }^{1}$ Robo, M., Xhavara, A., Bazat e Sipwrmarrjes, Tiranë 2012, p 27,28,29

2 Kompetencat e të mësuarit për të nxënë dhe të mësuarit të sipërmarrjes në arsimin e mesëm dhe në arsimin e lartë në Shqipëri, përgatitur nga Qendra për nxitjen dhe zhvillimin njerëzor, shkurt 2007, p 9-10.

${ }^{3}$ A key competence approach, The European Union's IPA Multi-beneficiary Programme, p 2-13

${ }^{4}$ A key competence approach, The European Union's IPA Multi-beneficiary Programme, p 26-27
} 
Some of main characteristics of entrepreneurial student are: ${ }^{1}$

To identify possibilities for activities; therefore, to have good knowledge for the working trade.

To be conscious of the position of entrepreneurship.

To plan, organize, manage, delegate, analyze, communicate.

To represent, to negotiate.

To work in an individually and in groups.

To know how to distinguish strong and weak points and to be able to take risks.

To take initiatives, to be active, to be independent and innovative in personal, social life and work.

To be motivated and decisive in relation to reach objectives and aims.

These are the characteristics of entrepreneurial student who should be taught in an entrepreneurial university. The later must have a crucial role about innovation, research and learning by having contacts with business world, promoting entrepreneurship learning in order to each the only result: What the student should know and what should be able to do.

\section{Problems that student face in relation to knowledge in relation to entrepreneurship}

What do students know about entrepreneurship and what are their needs in relation to entrepreneurship learning? To answer this question, there are used the results of the questionnaire competed by students of elementary education and kinder garden. There have been asked 283 students. Their age varies from 19 to 22 . The academic years vary from the first year to the fifth for elementary education students to be and from the first to the third year for students of kinder garden. The collected information from questionnaire was a great help to identify and categorize the needs of students in relation to entrepreneurship learning.

\section{Questions of the survey:}

Each of the questions of the survey was accompanied by options no, just, somehow, a lot and each students has to choose one of the four (not for every question of the survey, the students have marked one option). The number of students who have marked one of the above options it is named with $\mathrm{N}$.

Table number 1 shows the number of students divided according to the gender:

\begin{tabular}{|l|l|l|l|}
\hline Faculty & Number of students & Gender & Gender \\
\hline & & Female & male \\
\hline FES & 283 & 265 & 18 \\
\hline All & $283(100 \%)$ & $86 \%$ & $14 \%$ \\
\hline
\end{tabular}

FES = Faculty Education Sciences

In the first question of the survey: "In our faculty dominates student center learning" $22 \%$ of students have marked somehow and $79 \%$ of have marked just $(\mathrm{N}=283)$. Analyzing the percentages it could be said that this kind of teaching is not dominating I the auditory of the Faculty of Education Sciences; as student say in free discussions, most of lectors dictate lectures which makes problematic the development of learning to learning competence and analytical and creative thinking.

1 Projekti SEECEL, Zhvillimi SME në Shqipëri dhe të mësuarit për Sipërmarrjen, 1 mars 2012, Universiteti “A Xhuvani”, Elbasan, organizuar nga Ministria e Ekonomisë. 
In the second question: "this kind of teaching encourages analytical and creative thinking and problem solving", $97 \%$ of students have marked a lot and $3 \%$ have marked somehow $(\mathrm{N}=283)$. Based on the results of percentages, it could be said that in general students understand the importance of teaching that promotes creativity and problem solving.

In the third question: "to be rich and successful in Albania, it is important to be a good students" $42 \%$ have marked a lot and $31 \%$ have marked somehow; only $28 \%$ have marked no $(\mathrm{N}=283)$. A great number of students evaluate high results in learning, but most of them do not think that to be successful and rich must have these results.

In the fourth question: "In the last two years, the faculty has organized a lot of activities that have not been organized before", $78 \%$ of students have marked somehow and $21.9 \%$ of them have marked just little ( $N=283)$.

Based on results, it is clear that there are fewer activities organized compared with previous years. Discussing with students has resulted that they have never or rarely visited a company or factory, have rarely taught about the way they function or are presented to the ways of creating a company. They have rarely had the opportunity to know how to apply for a new job or who they may ask for help in case they have an idea for a job etc.

In the fifth question: "innovation is an important role in life of our faculty" $65 \%$ of students have marked just little, $20 \%$ of them have marked somehow and $15 \%$ of them have marked no $(\mathrm{N}=283)$. The percentages show that students are aware who now understand that organized task in a new way, making decisions independently, planning new activities etc, should be encouraged more and more.

In the sixth question: "a creative atmosphere in my university inspires me to practice ideas for new activities", $47 \%$ have marked somehow, 29. $9 \%$ have marked a lot and 23. $1 \%$ have marked just little $(\mathrm{N}=283)$. The answers in percentages of this question could be related to the questions number four and five. It could be said that in general, academic staff takes in consideration more working in auditory by neglecting working out of it.

In the seventh question: "entrepreneurial relation is the base of wellbeing from which everyone can profit" $41 \%$ have marked somehow and $59 \%$ have marked a lot $(\mathrm{N}=279)$.

In the eighth question "entrepreneurship may bring more values for faculty" $62 \%$ of the students have marked a lot and $38 \%$ of them have marked somehow $(\mathrm{N}=280)$.

In the ninth question: "entrepreneurship activities are in favor of the culture in our place", $80.3 \%$ of the students have marked somehow and $19.7 \%$ of them have marked a lot. $(\mathrm{N}=283)$.

Based on the above answers for three questions it could be said that entrepreneurial relation, entrepreneurship and entrepreneurial activities are perceived from most of the students as positive; even though from the free discussions that are done with students, it is noticed the fact that they do not clearly understand the concept of entrepreneurship. Therefore, they need to be clear about the entrepreneurial abilities of the student.

In the tenth question: "I think that entrepreneurial abilities 9competences) can be developed" $82 \%$ of the students have marked a lot and $18 \%$ have marked just little $(\mathrm{N}=283)$.

In the eleventh question: "entrepreneurial employers are creative at work", $64 \%$ of the students have marked a lot, $15 \%$ of them have marked somehow and $20.7 \%$ have marked little. $(\mathrm{N}=272)$.

In the twelfth question: "students should think of an entrepreneurial way", 52. $4 \%$ of the students have marked a lot and $39 \%$ of them have marked somehow $(\mathrm{N}=277)$.

In the thirteenth question: "My friends evaluate entrepreneurial activity as the most important compared to other activities and careers", $22.8 \%$ of the students have marked a lot, $58.1 \%$ of them have marked somehow and $20 \%$ of them have marked very little $(\mathrm{N}=198)$.

If the answers of the above questions are carefully analyzed and based on the discussions that are done with groups of students, it could be said that the term entrepreneurship is not often used among students. Despite intuits they need more information. 
In the fourteenth question: "entrepreneurial relations can be learnt", $61 \%$ of the students have marked somehow and $39 \%$ of them have marked a lot $(\mathrm{N}=283)$.

In the fifteenth question: "I think that concrete results are necessary in a way that professional success can be judged", 80 . $3 \%$ of the students have marked a lot and $19.7 \%$ have marked somehow $(N=243)$.

In the sixteenth question: "most of the people in my place consider unsuitable to be entrepreneurial" $64 \%$ of the students have marked little and $36 \%$ have marked no ( $N=261)$.

In the seventeenth question: "it is important for me to have a stable job", almost $100 \%$ of the students have marked a lot. $(\mathrm{N}=283)$.

\section{Conclusions:}

Although student center teaching has a good progress, it is not dominant in the auditory of Education Sciences Faculty. As students admit in their free conversations, a great number of lecturers dictate lectures, which makes very problematic the learning to learn competence development and developing analytical and creative thinking as well.

Based on the answers that students have provided, it could be said that in general they understand the importance of teaching that promotes creativity and problem solving, but it is needed more self-confidence, more courage from their professors who should work hard to use teaching methods by using more the methods that help more in reinforcing knowledge.

Most of the students do not link success or being rich with the learning success. It is thought that these perceptions happen as a result of the Albanian transition where working criteria have not been based and often are not based on individual abilities and competences of everyone.

An innovation would be to organize activities in order to help the curriculum, which is very theoretical. From students' discussions, it has resulted that they have never or very rarely visited a company or factory, have learned they way they function or are introduced the ways of creating a company. Furthermore, they have rarely had the chance to know how to apply in a new job, who could ask for help in case they have any working ideas etc. (These could serve as activities in relation to teaching and learning curricula).

Students have answered in relation to innovation as a new value of the faculty. It is understood that it has already started students' awareness who have already understood that organizing tasks in a new way, decision taking independently, planning new activities etc should be encourage more. It could be said that in general, academic staff shows more importance working in auditory than obviously minimizing the work outside auditory. Their job outside auditory is very tepid in relation to developing students' practical abilities in order to bring them near reality.

Based on students' answers, it could also be said that entrepreneurial relationship, entrepreneurship and entrepreneurial activities are perceived by most of the students as very positive; although it is noticed from the free discussions that they do not clearly understand the concept of entrepreneurship; therefore, they need to be cleared and to know what are and why are important the entrepreneurial abilities of the student.

\section{Recommendations:}

Based on the fact that most of the students are passive during the class, it is thought that it is very important that the professors and students should not consider themselves as two groups that stay in front of each other, where in most of the cases the professor dictates and students take notice; but they cooperate with each other. This cooperation would contribute in successful learning.

Learning should be considered not only as a way to gain knowledge, but as a process that develops students' abilities as well. The later should be aware that there are not enough only the traditional ways of learning such as underlining, reading, rereading the text until it is leant (the method that is widely used by our students). Students should be encouraged by their professors to enrich their methods of learning. Some other methods less traditional such as drawing charts, graphics based 
on text, using different resources such as books, internet, TV, different magazines etc would be very necessary and would help learning process.

Working outside auditory in order to develop students' practical abilities bringing them near reality would be very efficient. It is thought that this process would clearly influence in clarifying students about the concept of entrepreneurship, entrepreneurial activities and abilities.

Based on students' answers for questions number 10,11, 12, 13 and discussions organized with groups of students, it could be said that entrepreneurship is not often used between students. Despite their intuition, they need more information. Maybe a conceptual change of learning from students and professors as well would be very necessary. Being more transparent, it could be said that a very positive impact might have the relationships students - professors, where the later should try maximally that students change their traditional methods of learning. Another efficient way would be to give assignments in form of essays, research papers etc, individually or in groups, which should be done in our universities as part of students' studies considering them compulsory; in this way, it brings developing analytical and synthetic abilities for students by teaching them how to work individually and in groups.

It is thought that a separate subject, even titled "Education for Entrepreneurship" is very necessary. It would deal with basic entrepreneurial abilities that are needed for students of all branches.

\section{References:}

[1] A key competence approach, The European Union's IPA Multi-beneficiary Programme.

[2] Kompetencat e të mësuarit për të nxënë dhe të mësuarit të sipërmarrjes në arsimin e mesëm dhe në arsimin e lartë në Shqipëri, prepared by Qendra për nxitjen dhe zhvillimin njerëzor, February 2007.

[3] Projekti SEECEL, Zhvillimi SME në Shqipëri dhe të mësuarit për Sipërmarrjen, march 2012, Universiteti "A Xhuvani", Elbasan, organized by the Ministry of Economy.

[4] Robo, M. \& Xhavara, A. (2012), Bazat e Sipërmarrjes, Tiranë. 